\title{
Students' Creative Thinking Based on Motivation to Learn During Online Learning
}

\author{
Janet Trineke Manoy*, and Astridtia Putri Junita Sari \\ State University of Surabaya, Mathematics Department, Ketintang Surabaya, Indonesia
}

\begin{abstract}
This research aims to analyze high school students' creative thinking in solving mathematical problems based on learning motivation during online learning. This type of research is qualitative descriptive research. Five tenth grade students with different levels of learning motivation during online learning, each of which is a representative of the very good and good learning motivation group were chosen to be the subjects of this research. The instruments used in this research were an learning motivation questionnaire during online learning to measure the level of student learning motivation during online learning, mathematics problems to test students' creative thinking, and interview guidelines. The data on the results of the learning motivation questionnaire during online learning were analyzed using the Likert scale, the data on the results of the creative thinking test were analyzed based on components of creative thinking fluency, flexibility, novelty and the interview data were analyzed using the Analysis Interactive method from Miles and Huberman. The results of this study indicate that not all students with very good levels of motivation during online learning meet the components of creative thinking fluency, flexibility, and novelty. Students with a good level of motivation during online learning meet the creative thinking component, namely fluency.
\end{abstract}

Keyword. students' creative thinking, mathematics problems, learning motivation during online learning.

\section{Introduction}

The process of someone to come up with a new idea (novelty) is called creative thinking (Siswono, (2007); Huda, (2011); Sternberg (2003: 325-326); Anwar, Shamim-Ur-Rasool \& Haq (2012)). Mathematical creative thinking is a person's ability to produce solutions in new and different ways to open mathematical problems (Livne (2008); Yuliana (2015); and Mutaharah, et al (2018)). Facing a world situation that is always changing requires the ability to think creatively mathematically (Noer, 2009).In the era of society 5.0, creative thinking skills are one of the skills that must be mastered. This is as a result of people's literacy of information and communication technology (Sukarno, 2020). Not only that, the Directorate General of Teachers and Education Personnel (2018) states that 4C skills (critical thinking skills, creative thinking skills, communication, and collaboration) which include creative thinking skills, are very important and necessary for 21 st century education. The National Standards Agency Education (BSNP) (2010) says that creative thinking skills are life skills that must be mastered because these skills characterize quality human resources (HR), which are required from the development of science in the 21 st century. In Indonesia itself, efforts to prepare quality human resources in the 21 st century have been carried out, one of which is in the field of education with the implementation of the 2013 curriculum. Permendikbud 20/2016 states that the graduation competency standards in the 2013 curriculum must have creative, productive, independent, critical thinking skills, collaborative, and communicative. This shows that the competency standards in the 2013 curriculum which consist of 4C skills and the 2013 curriculum are designed to prepare quality human resources in the 21 st century.

Silver (1997) and Siswono (2007) describe three important components to assess a person's creativity, namely a) fluency: is the ability of students to solve problems with a variety of correct answers; b) flexibility: is the ability of students to solve problems in various ways; and c) novelty: is the ability of students to solve problems in a variety of ways that are unique to their level of knowledge. The ability to think creatively is influenced by several factors that can come from within a person (internal factors) including: gender, socioeconomic status, birth order, and intelligence or from outside a person (external factors) including: time, opportunity to gain knowledge, ways educating children, encouragement, non-possessive parent-child relationships, infrastructure, as well as a stimulating environment (Hurlock (1999)). Not only that, (Septi, et al, 2019) said that creative thinking skills are also influenced by student learning motivation.

\footnotetext{
* Corresponding author: janetmanoy@unesa.ac.id
} 
According to Hanurrani and Susanah (2019) students with high mathematical abilities do not necessarily have high levels of creative thinking skills and students with low mathematical abilities do not necessarily have low levels of creative thinking abilities. Then what about students' creative thinking when viewed from the motivation to learn during online learning during the current Covid-19 pandemic. Learning during the Covid19 pandemic must run online (Circular Letter of the Minister of Education and Culture of Indonesia no. 04 of 2020). The implementation of online learning certainly has many challenges and difficulties that can cause students' learning motivation to decrease. The decline in learning motivation can be influenced by several factors such as: teachers cannot monitor student activities during the learning process, students need direct verbal explanations from teachers, internet services in remote areas, and other complaints such as spending more money for online learning, and using gadgets excessive by students (Hafida, et al). Based on the explanation above, the researcher wants to research about "Analysis of Students' Creative Thinking in Solving Mathematical Problems in terms of Learning Motivation During Online Learning". This study aims to analyze students' creative thinking in solving mathematical problems in terms of learning motivation during online learning

\section{Methods}

\subsection{Research Subject}

This research is in the form of a qualitative descriptive, followed by 17 students of class X SMA who participate in filling out a questionnaire on learning motivation during online learning. This learning motivation questionnaire was developed based on indicators of learning motivation proposed by Hamzah B. Uno (2013). The questionnaire used consisted of 30 favorable and nonfavorable statements about students' learning motivation during online learning. In this study, a Likert Scale was used for scoring each statement in the questionnaire on learning motivation during online learning with alternative answers of always, often, sometimes, and never.

The highest score of the questionnaire is $4 \times 30=120$ and the lowest score is $1 \times 30=30$, so the range is 90 . Because the learning motivation scale used consists of four classes ( 1 to 4 ), the class interval is 22.5 and rounded to 23 (Widoyoko, 2015), so that the score limits for the learning motivation category are $99-121$ in the very good category, $76-98$ in the good category, $53-75$ in the fairly good category and $30-52$ in the less category.

Based on the results of the questionnaire on learning motivation during online learning, 5 subjects were taken, namely 2 subjects with very good learning motivation categories and 3 subjects with good learning motivation categories with the same gender and willingness to participate as control variables.

\subsection{Instrument}

The instruments used in this study are: a learning motivation during online learning questionnaire, test questions and interview guidelines. For data collection, using test questions designed by taking into account the creative thinking component of Silver (1997) and Siswono (2007), allowing students to demonstrate the components of fluency, flexibility, and novelty in their work. Mathematical problems used in the test, as shown in Figure 1 below

\section{CREATIVE TEST QUESTIONS}

Doni plans to build his dream house which consists of one living room, three bedrooms, each with the same area as- ${ }_{4}^{3}$ from the living room area, one family room which is the same as the bedroom area plus the living room area, the kitchen area is equal to twice the size of the bedroom, and the bathroom is in the kitchen. Help Doni to build his dream house

a) How much living room area can Doni use? (F1)

b) Calculate the area of the other room! (F2 and F3)

c) Can you calculate the area of another room in another way? (F2 and F3)

d) What is the minimum area of land that Doni needs to build his dream house? (F1)

e) Determine the other possible minimum land area! (F1)

Fig. 1. Creative thinking test questions

\subsection{Data Analysis}

The creative thinking component according to Silver (1997) and Siswono (2007) is used as a reference for data analysis of the subject's test results, as shown in Table 1 below.

Table 1. Creative Thinking Component

\begin{tabular}{|l|l|l|l|}
\hline No. & $\begin{array}{l}\text { Creative } \\
\text { Thinking } \\
\text { Component }\end{array}$ & Indicator & Code \\
\hline 1 & Fluency & $\begin{array}{l}\text { Students can solve } \\
\text { problems with various } \\
\text { interpretations of } \\
\text { answers or solutions. } \\
\text { (at least two } \\
\text { alternative solutions) }\end{array}$ & F1 \\
\hline 2 & Flexibility & $\begin{array}{l}\text { Students can observe } \\
\text { from different points } \\
\text { of view or students } \\
\text { can solve problems } \\
\text { with different ways. } \\
\text { (at least two different } \\
\text { ways) }\end{array}$ & F2 \\
\hline
\end{tabular}




\begin{tabular}{|l|l|l|l|}
\hline 3 & Novelty & $\begin{array}{l}\text { Students can provide } \\
\text { ideas that are } \\
\text { relatively new or in } \\
\text { their own way in } \\
\text { solving problems and } \\
\text { students can make } \\
\text { combinations of } \\
\text { answers that are not } \\
\text { commonly used. }\end{array}$ & F3 \\
\hline
\end{tabular}

Furthermore, the results of the interviews were analyzed using the Analysis Interactive model of Miles and Huberman with three stages, namely reducting data, displaying data, and drawing conclusions and verification

\section{Result and Discussion}

Based on the data analysis of the results of the questionnaire on learning motivation during online learning, 5 research subjects were selected, namely 2 subjects with very good motivation categories and 3 subjects with good motivation categories. The classification of the 5 subjects is presented in Table 2 below.

Table 2. Classification of Reseacrh Subject

\begin{tabular}{|c|c|c|c|c|}
\hline No. & $\begin{array}{l}\text { Subject } \\
\text { Name }\end{array}$ & $\begin{array}{l}\text { Learning } \\
\text { Motivatio } \\
\mathrm{n} \\
\text { Questionn } \\
\text { aire Score }\end{array}$ & $\begin{array}{c}\text { Classificat } \\
\text { ion of } \\
\text { Learning } \\
\text { Motivatio } \\
\text { n Levels } \\
\text { During } \\
\text { Online } \\
\text { Learning }\end{array}$ & $\begin{array}{l}\text { Subject } \\
\text { Code }\end{array}$ \\
\hline 1 & AEA & 109 & $\begin{array}{c}\text { Very } \\
\text { Good } \\
\text { Learning } \\
\text { Motivatio } \\
\text { n } 1\end{array}$ & MSB \\
\hline 2 & FA & 105 & $\begin{array}{c}\text { Very } \\
\text { Good } \\
\text { Learning } \\
\text { Motivatio } \\
\text { n } 2 \\
\end{array}$ & ISB \\
\hline 3 & LNA & 92 & $\begin{array}{c}\text { Good } \\
\text { Learning } \\
\text { Motivatio } \\
\text { n } 1 \\
\end{array}$ & MB1 \\
\hline 4 & NDL & 93 & $\begin{array}{c}\text { Good } \\
\text { Learning } \\
\text { Motivatio } \\
\text { n } 2 \\
\end{array}$ & MB2 \\
\hline 5 & MW & 90 & $\begin{array}{c}\text { Good } \\
\text { Learning } \\
\text { Motivatio } \\
\text { n } 3\end{array}$ & IB \\
\hline
\end{tabular}

Based on the data analysis of the test results and the results of interviews with the 5 subjects above, it can be described as follows

\subsection{Creative Thinking of Student With Very Good Learning Motivation 1 (MSB)}

MSB solves test questions in the form of mathematical problems as shown in Figure 2,3, and 4 below.

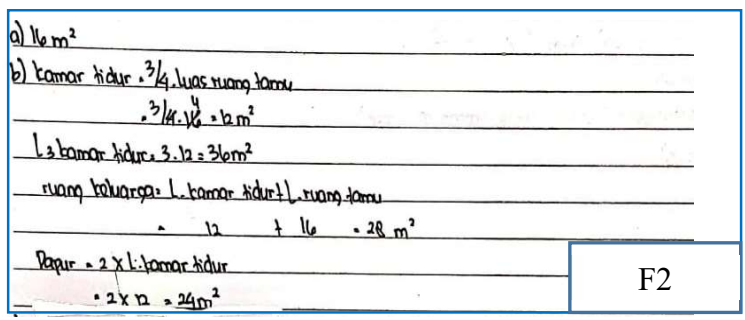

Fig. 2.MBS's Answer

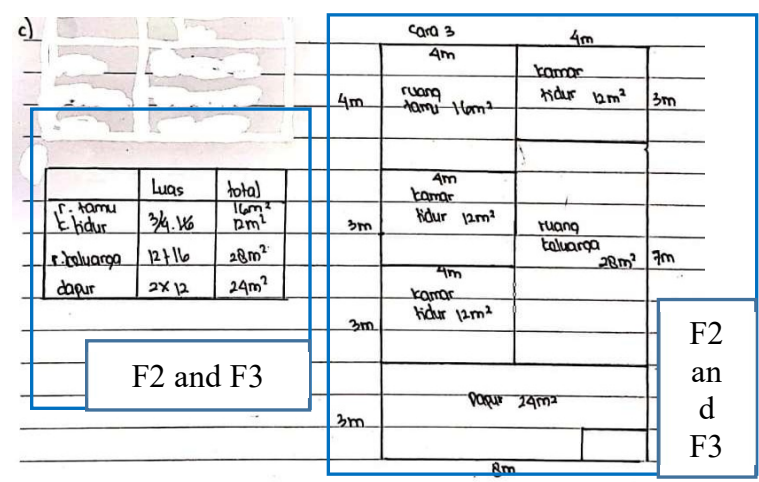

Fig. 3. MBS's Answer

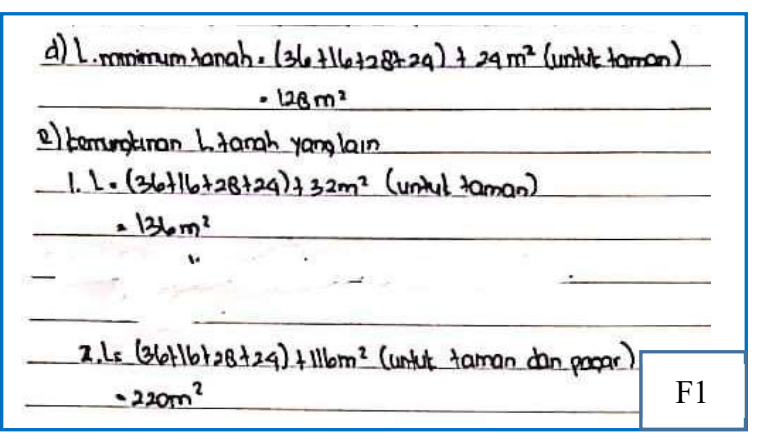

Fig. 4. MBS's Answer

Based on the answers written in Figure 2,3, and 4, MSB fulfills three components of creative thinking, namely fluency, flexibility, and novelty (Silver, 1997 and Siswono, 2007). MSB can provide answers more than two minimum land sizes needed to build a house, based on Hanurrani and Susanah (2019) that "Students meet the fluency criteria if they can provide at least two alternative solutions", meaning that MBS meets the fluency requirements marked with the F1 code. MSB can calculate the area of each room in the house to be built using more than two ways, based on Hanurrani and Susanah (2019) that, "Students meet the flexibility criteria if they can provide at least two ways of making alternative solutions", meaning that MBS meets the flexibility 
requirements. marked with the F2 code. MSB can calculate the area of each room in a new way (the subject itself and not used by other students) by calculating the area of each room with a table and drawing a house plan to be built and then calculating the area of each room, based on Hanurrani and Susanah (2019) that, "Students meet the criteria for novelty if they can provide a different way from the others" means that MBS meets the requirements for novelty marked with the F3 code. Based on the results of interviews, MSB can achieve three components of creative thinking. The following is an excerpt from an interview with MSB.

Q : Did you find other answers to the questions given?

MSB : Yes

From the interview excerpts, MSB can determine more than two sizes of the minimum area of land needed to build a house. This shows that the MSB meets the fluency requirements.

Q : Can you solve the given problem in another way? If you can, try to mention other ways that can be used!

MSB :Yes, I calculate the area of each room by systematically registering it with a table and secondly, I calculate the area of each room with the help of a house plan to be built.

\subsection{Creative Thinking of Student With Very Good Learning Motivation 2 (ISB)}

solves test questions in the form of math problems as shown in Figure 5 and 6 below.

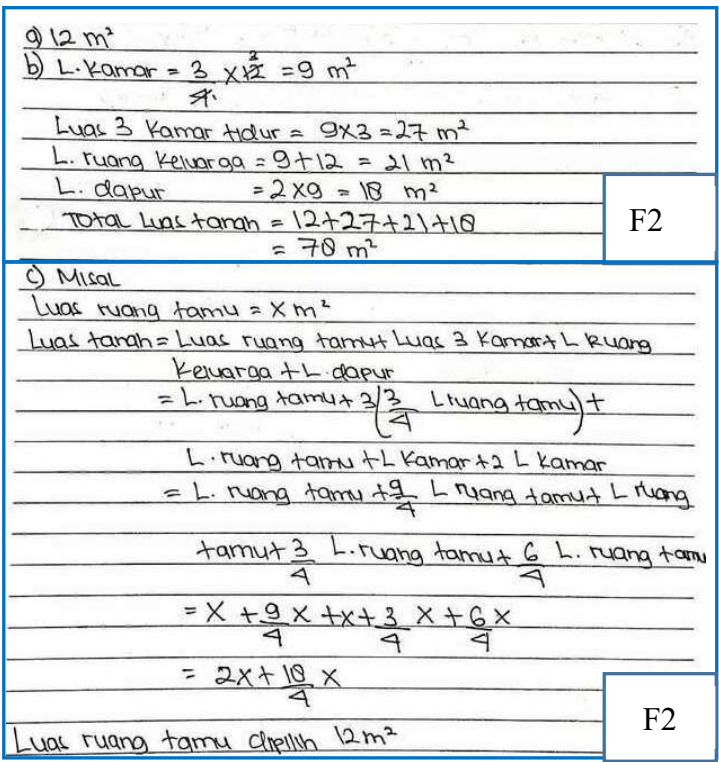

Fig. 5. IBS's Answer
Q : How do you solve the given problem using another way?

MSB : For another method, the first thing I did was to make a table first, then I entered the area of each room into the table systematically, after that I determined the minimum area of land needed to build a house. For another second way, I do it by first making a plan of the house to be built and then calculating the area of the room one by one according to the plan after that I determine the minimum area of land needed to build a house.

From the interview excerpts, MSB was able to work on the test questions using more than two ways. This shows that MBS meets the flexibility requirements.

Q : In solving the problems given, can you use your own method?

MSB : Yes

Q : How do you solve the given problem using a new method (your own way)?

MSB : The method is in accordance with the other methods that I have described previously.

From the interview excerpts, MSB can do the test questions in his own way, by calculating the area of each room using tables and plans for the house to be built. This shows that MSB meets the novelty requirements.

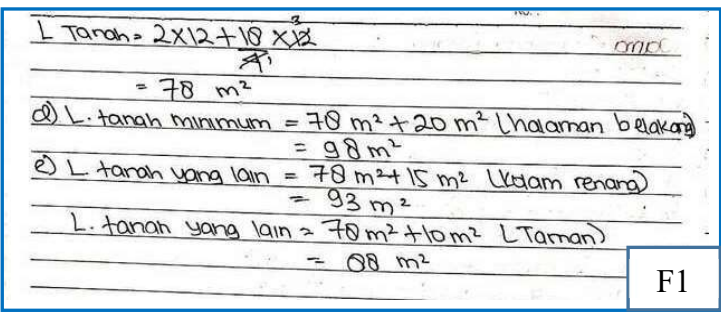

Fig. 6. IBS's Answer

Based on the answers written in Figure 5 and 6, ISB fulfills two components of creative thinking, namely fluency and flexibility (Silver, 1997 and Siswono, 2007). ISB can provide answers more than two minimum land sizes needed to build a house, based on Hanurrani and Susanah (2019) that, "Students meet the fluency criteria if they can provide at least two alternative solutions", meaning that ISB meets the fluency requirements marked with the F1 code. ISB can calculate the area of each room in the house to be built in two different ways, based on Hanurrani and Susanah (2019) that, "Students meet the flexibility criteria if they can provide at least two ways of making alternative solutions", meaning ISB meets the flexibility requirements marked with $\mathrm{F} 2$ code. ISB can't use the new method, so it is concluded that the ISB does not meet the requirements of novelty. At the time of the interview ISB can achieve two components of creative thinking. The following is an excerpt from an interview with ISB.

Q : Did you find other answers to the questions given ?

ISB : Yes. 
From interview excerpts, the ISB can determine more than two sizes of the minimum area of land needed to build a house. This shows that the ISB meets the fluency requirements.

Q : Can you solve the given problem in another way? If you can, try to mention other ways that can be used!

ISB : Yes, I can calculate the area of each room using the concept of a one-variable linear equation

Q : How do you solve the given problem using another way?

ISB : I assume the area of the living room with the variable $\mathrm{x}$ then I solve according to what is known in the problem and according to the concept of a one-variable linear equation.

From the interview excerpts, the ISB does the test in two different ways. This shows that the ISB meets the flexibility requirements.

Q : In solving the given problem, can you use your own method?

ISB : Can not.

From the interview excerpts, ISB does not do the test questions given in his own way. This shows that the ISB does not meet the requirements of novelty.

\subsection{Creative Thinking of Student With Good Learning Motivation 1 (MB1)}

MB1 solves test questions in the form of math problems as shown in Figure 7 and 8 below.

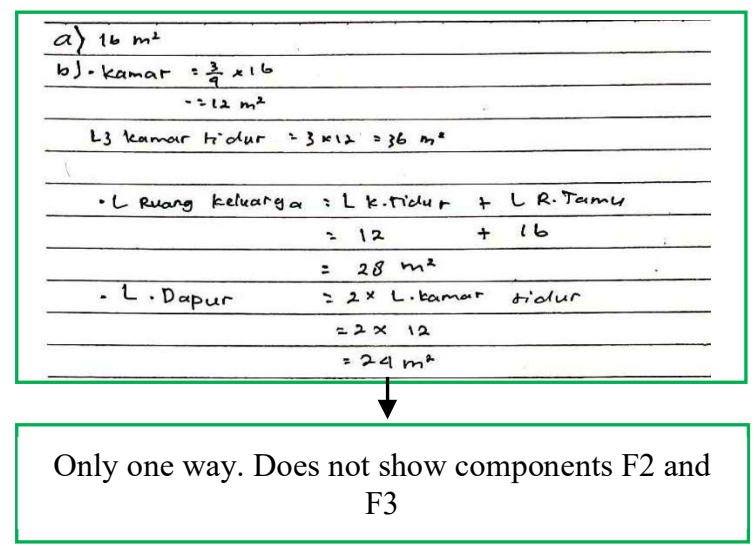

Fig. 7. MB1's Answer

\begin{tabular}{|c|c|}
\hline \multicolumn{2}{|l|}{ c) Tidak. } \\
\hline \multicolumn{2}{|c|}{ d) $\left(36 m^{2}+16 m^{2}+20 m^{2}+29 m^{2}\right)+30 m^{2}$ (untuk taman) } \\
\hline \multicolumn{2}{|l|}{$1=134 \mathrm{~m}^{2}$} \\
\hline e) kemungkinan L. tanah yang lain & \multirow{3}{*}{ F1 } \\
\hline (1). $140 \mathrm{~m}^{2}$ dg Ukuran L. Taman $39 \mathrm{~m}^{2}$ & \\
\hline (2) $195 \mathrm{~m}^{2}$ dg Ukuran L.Taman $39 \mathrm{~m}^{2}$ & \\
\hline
\end{tabular}

Fig. 8. MB1's Answer

Based on the answers written in Figure 7 and 8, MB1 fulfills one component of creative thinking, namely fluency (Silver, 1997 and Siswono, 2007). MB1 can answer more than two minimum area of land needed to build a house, based on Hanurrani and Susanah (2019) that, "Students meet the fluency criteria if they can provide at least two alternative solutions", meaning MB1 meets the fluency requirements marked with the F1 code. MB1 does not write any other way, so it can be concluded that MB1 does not meet the requirements of flexibility and novelty. At the time of the interview MB1 can achieve one component of creative thinking. The following is an excerpt from an interview with MB1.

Q : Did you find other answers to the questions given?

MB1: Yes

From the interview excerpts, MB1 can determine more than two sizes of the minimum area of land needed to build a house. This shows that MB1 meets the fluency requirements.

Q : How did you find the answers to the questions given?

MB1: First I calculate the area of each room then determine the minimum area of land needed to build a house

Q : Can you solve the given problem in another way? If you can, try to mention other ways that can be used!

MB1: Can't

From the interview excerpts, MB1 can do the test in one way so it can be concluded that MB1 does not meet the flexibility requirements.

Q : In solving the given problem, can you use your own method?

MB1: Can't.

From the interview excerpts, MB1 cannot do the test questions in his own way, this shows that MB1 does not meet the novelty requirements.

\subsection{Creative Thinking of Student With Good Learning Motivation 2 (MB2)}

Online MB2 solves test questions in the form of math problems, as shown in Figure 9 and 10 below.

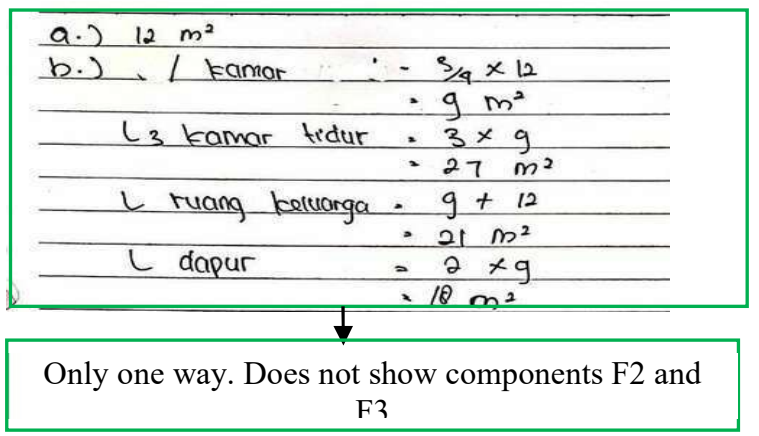

Fig. 9. MB2's Answer 


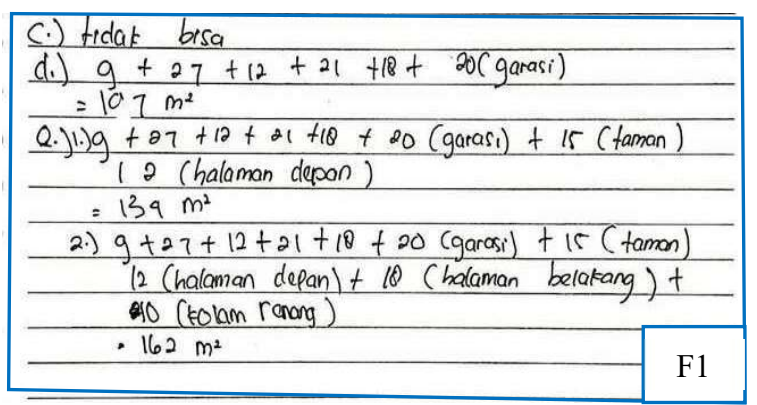

Fig. 10. MB2's Answer

Based on the answers written in Figure 9 and 10, MB2 fulfills one component of creative thinking, namely fluency (Silver, 1997 and Siswono, 2007). MB2 can provide answers in more than two minimum area of land needed to build a house, based on Hanurrani and Susanah (2019) that "Students meet the fluency criteria if they can provide at least two alternative solutions", meaning MB2 meets the fluency requirements marked with the F1 code. MB2 did not write another way to calculate the area of each room, so it was concluded that MB2 did not meet the requirements of flexibility and novelty. At the time of the interview MB2 can achieve one component of creative thinking. The following is an excerpt from an interview with MB2

Q : Did you find other answers to the questions given?

MB2 : Yes

From interview excerpts, MB2 can determine more than two sizes of the minimum area of land needed to build a house. This shows that MB2 meets the fluency requirements.

Q : How did you find the answers to the questions given?

MB2 : First I calculate the area of each room and then determine the minimum area of land needed to build a house by adding up the area of each room.

Q : Can you solve the given problem in another way? If you can, try to mention other ways that can be used!

MB2 : Can not.

From the interview excerpts, MB2 can do the test in one way, so it is concluded that MB2 does not meet the flexibility requirements.

Q : In solving the given problem, can you use your own method?

MB2 : Can't.

From the results of the interview, MB2 could not do the test questions in his own way, this shows that MB2 does not meet the novelty requirements.

\subsection{Creative Thinking of Student With Good Learning Motivation 3 (IB)}

IB solves test questions in the form of math problems as shown in Figure 11 below.

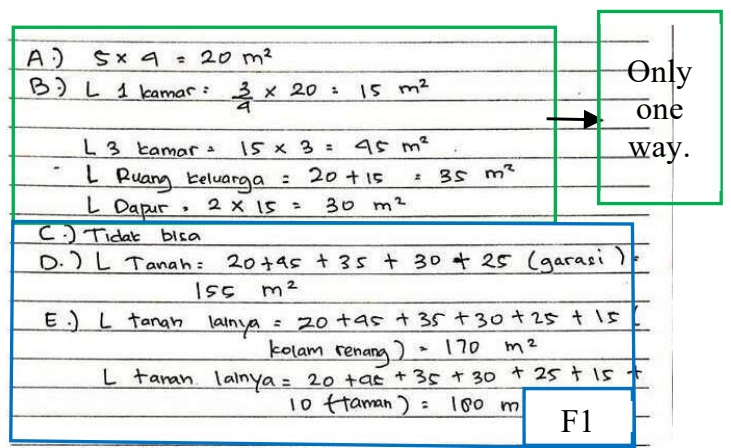

Fig. 11. IB's Answer

Based on the answers written in Figure 11, IB can fulfill one component of creative thinking, namely fluency (Silver, 1997 and Siswono, 2007). IB can provide answers in more than two minimum area of land needed to build a house, according to the statement of Hanurrani and Susanah (2019) that, "Students meet the fluency criteria if they can provide at least two alternative solutions", meaning that IB meets the fluency requirements marked with the F1 code. IB does not use other methods to calculate the area of each room, so it is concluded that IB does not meet the requirements for flexibility and novelty. At the time of the interview IB can achieve one component of creative thinking. The following is an excerpt from an interview with IB.

Q : Did you find other answers to the questions given?

IB : Yes

From the interview excerpts, the IB can determine more than two sizes of the minimum area of land needed to build a house. This shows that the IB meets the fluency requirements.

Q : How did you find the answers to the questions given?

IB : I calculated the area of each room and then determined the minimum area of land.

Q : Can you solve the given problem in another way? If you can, try to mention other ways that can be used!

IB : Can't

From the interview excerpts, the IB can work on the questions in one way so it can be concluded that the IB does not meet the flexibility requirements.

$\mathrm{Q}$ : In solving the given problem, can you use your own method?

IB : No.

From the results of the interview, the IB cannot do the questions in his own way, this shows that the IB does not meet the requirements for novelty.

\section{Conclusion}

Based on the data analysis of test results and interview results, it can be concluded as follows.

1. Not all students with a very good level of learning motivation during online learning meet the three components of creative thinking. MSB and ISB have very good learning motivation but meet the 
different components of creative thinking according to Silver (1997) and Siswono (2007).

2. Students with a good level of learning motivation during online learning fulfill one component of creative thinking according to Silver (1997) and Siswono (2007), namely Fluency.

\section{References}

1. Badan Standar Nasional Pendidikan, Paradigma Pendidikan Nasional Abad XXI, (2010)

2. C.A. Hanurrani, and Susanah, Kemampuan Berpikir Kreatif Siswa Dalam Menyelesaikan Masalah Matematika Open Ended Ditinjau Dari Kemampuan Matematika, Jurnal Ilmiah Pendidikan Matematika. 8(2), 7 - 14, (2019)

3. C. Huda, Meningkatkan Kemampuan Berpikir Kreatif Siswa dalam Memecahkan Masalah Matematika dengan Model Pembelajaran Treffinger pada Materi Pokok Keliling dan Luas Persegipanjang, (Online), (http://digilib.uinsby.ac.id/9360/)

4. Direktorat Jenderal Guru dan Tenaga Kependidikan Kementerian Pendidikan dan Kebudayaan, Buku Pedoman Pembelajaran Berorientasi pada Keterampilan Tingkat Tinggi, (2018)

5. E. A. Silver, Fostering Creativity through Instruction Rich in Mathe- matical Problem Solving and Problem Posing, Zentralblatt fur Didaktik der Mathematik (ZDM), (1997)

6. Ek. Widoyoko, Teknik Penyusunan Instrumen Penelitian, (2015)

7. E. Yuliana, Pengembangan Soal Open Ended Pada Pembelajaran Matematika Untuk Mengidentifikasi Kemampuan Berfikir Kreatif Siswa. Prosiding Seminar Nasional Pendidikan Matematika (SNAPTIKA), (2015)

8. Hafida, etc., Penurunan Motivasi dan Keaktifan Belajar Siswa Selama Pembelajaran Daring di Tengah Pandemi Covid - 19, (no year)

9. H. B. Uno, Teori Motivasi dan Pengukurannya, (2013)

10. Muthaharah, etc, Analisis Kemampuan Berpikir Kreatif Matematis Siswa SMP dalam Menyelesaikan Soal Bangun Ruang Sisi Datar, JMP, 2(1), 63 - 75, (2018)

11. M. B. Miles, and M. Huberman, Analisis Data Kualitatif, (1992)

12. M. N. Anwar, S. Shamim-ur-Rasool, R Haq, A Comparison of Creative Thinking Abilities of High and Low Achievers Secondary School Students, International Interdisciplinary Journal of Education, 1(1), 3 - 8, (2012)

13. M. Sukarno, Penguatan Pendidikan Karakter Dalam Era Masyarakat 5.0, Prosiding Seminar Nasional 2020 Fakultas Psikologi UMBY, (2020)

14. N. L. Livne, Enhancing Mathematical Creativity Through Multiple Solution to Open-Ended Problems Online, (Online).
(https://www.researchgate.net/profile/CharlesWight-2/publication/228862669.,)

15. Permendikbud Nomor 20 tentang Standar Kompetensi Lulusan Pendidikan Dasar dan Menengah, (2016)

16. R. J. Sternberg, Creative Thinking in The Classroom, Scandinavian Journal of Education Research,47(3), 325-338, (2003)

17. Septi, etc, Motivasi Belajar Terhadap Kemampuan Berpikir Kreatif Matematis Siswa, JOE,1(3), 498 506, (2019)

18. S. H. Noer, Kemampuan Berpikir Kreatif Matematis. Apa, Mengapa dan Bagaimana. Prosiding Seminar Nasional Pendidikan dan Penerapan MIPA Universitas Negeri Yogyakarta, (2009)

19. Surat Edaran Kementrian Pendidikan dan Kebudayaan Nomor 4 Tahun 2020 tentang Pelaksanaan Kebijakan Pendidikan dalam masa darurat penyebaran virus Corona

20. T. Y. E. Siswono, Desain Tugas untuk Mengidentifikasi Kemampuan Berpikir Kreatif Siswa dalam Mate- matika, Jurnal (Online). Siswono, (2007) 